\title{
COMMENTARY
}

\section{Don't miss the diagnosis of sepsis!}

\author{
Paul E Marik
}

See related research by Garnacho-Montero et al., http://ccforum.com/content/18/3/R116

\begin{abstract}
The early detection and treatment of sepsis are the most important factors in improving the outcome of patients with this condition. However, many patients admitted to hospital experience a long delay in the diagnosis of sepsis. Furthermore, it is not uncommon for febrile patients to be sent home from the Emergency Department or the physician's office with the diagnosis of 'flu' only to return hours or days later in overt septic shock. The early diagnosis of sepsis may be challenging as many of the signs and symptoms are non-specific. Clinical studies suggest that early diagnosis of sepsis requires a high index of suspicion and comprehensive clinical evaluation together with laboratory tests, including a complete blood count with differential, lactate and procalcitonin levels.
\end{abstract}

\section{Introduction}

Sepsis is amongst the most common reasons for admission to ICUs throughout the world. The early detection and timely administration of appropriate antibiotics are the most important factors in improving the outcome of patients with sepsis. However, the initial signs and symptoms of sepsis are frequently non-specific, leading to a delay in diagnosis. Furthermore, the diagnostic characteristics of the systemic inflammatory response syndrome (SIRS) are not useful in distinguishing infectious from non-infectious causes of SIRS. An elevated white blood count, neutrophilia or eosinopenia are frequently used to diagnose bacterial sepsis; however, these variables have low diagnostic value.

\section{Biomarkers to diagnose sepsis}

Blood cultures are considered the clinical gold standard for the diagnosis of bacterial infections. However, blood

Correspondence: marikpe@evms.edu

Division of Pulmonary and Critical Care Medicine, Eastern Virginia Medical School, Norfolk, VA 23507, USA cultures are only positive in 20 to $30 \%$ of patients with sepsis; moreover, it takes 2 to 3 days before the results become available. As the clinical diagnosis of sepsis can be challenging and microbiological tests are unhelpful, several biomarkers have been developed to assist in the early diagnosis of sepsis, including procalcitonin (PCT), C-reactive protein (CRP) and, more recently, circulating cell-free DNA (cfDNA). In a well conducted study reported in a previous edition of Critical Care, GarnachoMontero and colleagues [1] investigated the role of these biomarkers in distinguishing infectious from noninfectious SIRS. They demonstrated that PCT had excellent diagnostic accuracy (area under curve (AUC) 0.87; 95\% confidence interval (CI) 0.81 to 0.94 ), that for CRP was modest (AUC $0.69 ; 95 \%$ CI 0.59 to 0.79 ) while that for cfDNA was poor (AUC 0.5; 95\% CI 0.61 to 0.71 ). The findings of this study are remarkably similar to the results of a recent meta-analysis performed by Wacker and colleagues [2]. In this meta-analysis the sensitivity of PCT for the diagnosis of sepsis was 0.77 (95\% CI 0.72 to 0.81 ), the specificity was 0.79 ( $95 \% \mathrm{CI} 0.74$ to 0.84$)$ and the area under the receiver operator characteristic curve was 0.85 (95\% CI 0.81 to 0.88 ). Tromp and colleagues [3] studied a panel of biomarkers in patients presenting to the Emergency Department with suspected sepsis. In this study PCT had the best predictive value for bacteremia (AUC 0.80). Similarly, Su and colleagues [4] evaluated 32 clinical signs, symptoms and laboratory tests available during a patient's stay in the Emergency Department that were predictive of bacteremia. In this study, PCT was the variable with the best diagnostic accuracy. Furthermore, thrombocytopenia, lymphocytopenia and bandemia were also predictive of bacteremia. Additional studies have confirmed that bandemia has a high predictive value for the diagnosis of sepsis [5]. Bacterial sepsis is typically characterized by neutrophilia and lymphocytopenia. While the total white blood cell count and neutrophil count are poor predictors of sepsis [4,5], an increased neutrophil to lymphocyte count ratio has been shown to be a useful marker of sepsis [6]. Molecular methods 
based on polymerase chain reaction technology are currently being investigated and hold promise for the early diagnosis of bacterial infection and pathogen identification $[7,8]$.

The use of PCT for the diagnosis of sepsis is controversial [9]; however, clinical studies suggest that PCT is currently the most useful biomarker to aid in its diagnosis. In healthy individuals, PCT levels are very low $(<0.01 \mathrm{ng} / \mathrm{ml})$ while in patients with bacterial sepsis the levels increase dramatically, sometimes to more than several hundred nanograms per milliliter. A PCT level $>0.5 \mathrm{ng} / \mathrm{ml}$ is highly suggestive of a bacterial infection while a level $<0.1 \mathrm{ng} / \mathrm{ml}$ makes this diagnosis less likely [10]. However, the optimal diagnostic threshold is unclear and has been reported to vary from 0.25 to $1.4 \mathrm{ng} / \mathrm{ml}[3,10]$. This variation in diagnostic threshold may partly be explained by the case mix of each study and the fact that patients with Gram-negative infection have significantly higher PCT levels than those with Gram-positive infections [11-13]. Infection with a Gramnegative pathogen is highly likely in a patient with a PCT level $>5 \mathrm{ng} / \mathrm{ml}$. It should be noted that patients with fungal infections usually have much lower or 'normal' PCT level [11].

It is important to emphasize that the PCT assay can yield both false positive and false negative results. Furthermore, there is no perfect 'sepsis test'. The diagnosis of sepsis requires a high index of suspicion. However, one or more of the parameters listed in Table 1 should increase the diagnostic likelihood of sepsis. These parameters are readily available on admission to the hospital or in the Emergency Department and should be obtained to support the diagnosis of sepsis. In many patients who present to the Emergency Department the diagnosis of sepsis is obvious - high fever, high white blood count and an obvious source of infection. However, not uncommonly patients with sepsis may present with vague constitutional symptoms, mild hypotension and tachycardia or with a fever and myalgia that are attributed

\section{Table 1 Diagnostic features suggestive of sepsis}

\begin{tabular}{ll}
\hline Diagnostic criteria & Threshold \\
\hline Fever & $>38.3^{\circ} \mathrm{C}$ \\
Tachycardia & $>120 / \mathrm{minute}$ \\
Systolic blood pressure & $<90 \mathrm{mmHg}$ \\
Procalcitonin & $>0.5 \mathrm{ng} / \mathrm{ml}$ \\
Bandemia & $>5 \%$ \\
Lymphocytopenia & $<0.5 \times 10^{3} \mathrm{ul}$ \\
or neurophil/lymphocyte ratio & $>10$ \\
Thrombocytopenia & $<150 \times 10^{3} \mathrm{ul}$ \\
Lactate & $>2.0 \mathrm{meq} / \mathrm{l}$ \\
\hline
\end{tabular}

to 'a viral syndrome'. These patients should not be sent home without further workup, unless they obviously have a viral syndrome and epidemiological data support the diagnosis of influenza.

\section{Conclusion}

When the diagnosis of sepsis is not clear we recommend a complete blood count with differential, blood lactate level and PCT as well as appropriate bacteriological cultures.

\section{Abbreviations}

AUC: Area under curve; cfDNA: Circulating cell-free DNA; Cl: Confidence interval; CRP: C-reactive protein; PCT: Procalcitonin; SIRS: Systemic inflammatory response syndrome.

\section{Competing interests}

The author declares that he has no competing interests.

Published online: 27 September 2014

\section{References}

1. Garnacho-Montero J, Huici-Moreno MJ, Gutierrez-Pizarraya A, Lopez I, Marquez-Vacaro JA, Macher HC, Guerrero JM, Puppo-Moreno A: Prognostic and diagnostic value of eosinopenia, C-reactive protein, procalcitonin, and circulating cell-free DNA in critically ill patients admitted with suspicion of sepsis. Crit Care 2014, 18:R116.

2. Wacker C, Prkno A, Brunkhorst FM, Schlattmann P: Procalcitonin as a diagnostic marker for sepsis: a systematic review and meta-analysis. Lancet Infect Dis 2013, 13:426-435.

3. Tromp M, Lansdorp B, Bleeker-Rovers CP, Gunnewiek JM, Kullberg BJ, Pickkers P: Serial and panel analyses of biomarkers do not improve the prediction of bacteremia compared to one procalcitonin measurement. $J$ Infect 2012, 65:292-301.

4. Su CP, Chen TH, Chen SY, Ghiang WC, Wu GH, Sun HY, Lee CC, Wang JL, Chang SC, Chen YC, Yen AM, Chen WJ, Hsueh PR: Predictive model for bacteremia in adult patients with blood cultures performed at the emergency department: a preliminary report. J Microbiol Immunol Infect 2011, 44:449-455.

5. Cavallazzi R, Bennin CL, Hirani A, Gilbert C, Marik PE: Is the band count useful in the diagnosis of infection? An accuracy study in critically ill patients. J Intensive Care Med 2010, 25:353-357.

6. de Jager CP, van Wijk PT, Mathoera RB, de Jongh-Leuvenink J, van der Poll T, Wever PC: Lymphocytopenia and neutrophil-lymphocyte count ratio predict bacteremia better than conventional infection markers in an emergency care unit. Crit Care 2010, 14:R192

7. Renvoise A, Brossier F, Sougakoff W, Jarlier V, Aubry A: Broad-range PCR: past, present, or future of bacteriology? Med Mal Infect 2013 43:322-330.

8. Motoshima M, Yanagihara K, Morinaga Y, Matsuda J, Hasegawa H, Kohno S, Kamihira S: Identification of bacteria directly from positive blood culture samples by DNA pyrosequencing of the 16S rRNA gene. J Med Microbiol 2012, 61:1556-1562.

9. Jones AE, Fiechtl JF, Brown MD, Ballew JJ, Kline JA: Procalcitonin test in the diagnosis of bacteremia: a meta-analysis. Ann Emerg Med 2007, 50:34-41

10. Schuetz P, Chiappa V, Briel M, Greenwald JL: Procalcitonin algorithms for antibiotic therapy decisions: a systematic review of randomized controlled trials and recommendations for clinical algorithms. Arch Intern Med 2011, 171:1322-1331.

11. Brodska H, Malickova K, Adamkova V, Benakova H, Stastna MM, Zima T: Significantly higher procalcitonin levels could differentiate Gramnegative sepsis from Gram-positive and fungal sepsis. Clin Exp Med 2014, 13:165-170.

12. Feezor RJ, Oberholzer C, Baker HV, Novick D, Rubinstein M, Moldawer LL, Pribble J, Souza S, Dinarello CA, Ertel W, Oberholzer A: Molecular characterization of the acute inflammatory response to infections 
with gram-negative versus gram-positive bacteria. Infect Immun 2003, 71:5803-5813.

13. Charles PE, Ladoire S, Aho S, Quenot JP, Doise JM, Prin S, Olsson NO, Blettery B: Serum procalcitonin elevation in critically ill patients at the onset of bacteremia caused by either Gram negative or Gram positive bacteria. BMC Infect Dis 2008, 8:38.

doi:10.1186/s13054-014-0529-6

Cite this article as: Marik: Don't miss the diagnosis of sepsis! Critical Care 2014 18:529. 